\title{
IN BED WITH AN EGYPTIAN PRINCESS: HERODOTUS ON THEFT, PYRAMIDS AND CONQUEST $^{1}$
}

\section{EN LA CAMA CON UNA PRINCESA EGIPCIA: HERÓDOTO SOBRE ROBOS, PIRÁMIDES Y CONQUISTAS}

\section{Carmen SÁNCHEZ-MAÑAS}

\section{Author / Autora:}

Carmen Sánchez-Mañas

Universidad de Murcia

Murcia, Spain

c.sanchezmanas@um.es

https://orcid.org/0000-0001-6309-9296

Submitted / Recibido: 01/02/2021

Accepted / Aceptado: 08/04/2021

To cite this article / Para citar este artículo: Sánchez-Mañas, C. (2022). In bed with an Egyptian princess: Herodotus on theft, pyramids and conquest. Feminismo/s, 39, 267-285. https://doi.org/10.14198/ fem.2022.39.10

Licence / Licencia:

This work is licensed under a Creative Commons Attribution 4.0 International.

\section{(c) (1)}

(C) Carmen Sánchez-Mañas

\begin{abstract}
Following in the footsteps of Homer, both in the Iliad and in the Odyssey, Herodotus of Halicarnassus gives women a very conspicuous presence in the only work attributed to him, known as the Histories. Usually, the women who appear in his work are directly related to prominent male characters. In this respect, daughterhood is one of the most distinct roles played by women in Herodotus' Histories. Twelve of the women actively involved in the narrative written by the author of Halicarnassus are identified as daughters of kings, tyrants or other noblemen, both of Greek and barbarian origin. Among the available examples, in this paper we focus on three Egyptian princesses, daughters of the pharaohs Rhampsinitus, Cheops and Amasis -in reality, Apries-, because they constitute precious instances for exploring the tensions arising in parent-child relationships in the Herodotean work. We aim at determining whether these princesses are individually fulfilled as characters, despite being sexually
\end{abstract}

1. I am very grateful to the reviewers for their careful reading of this paper and their insightful and enlightening suggestions. 
dominated daughters by their fathers, either biological other putative. To this end, we conduct an in-depth analysis of the three passages in which they appear (Hdt. 2.121e; $2.126 ; 3.1$ ), taking into account why and under what circumstances they are sexually controlled, how they interact with their fathers and other male characters and what consequences the sexual control they are subjected to has on them. Results show that the three Egyptian princesses achieve their own fulfilment as a wife, builder and avenger, respectively. We conclude that Herodotus confers on them visibility, dignity and their own non-transferable personality.

Keywords: concubinage; daughters; fathers; Greek views on Ancient Egypt; Herodotus' Histories; prostitution.

\section{Resumen}

Siguiendo la estela de Homero en la Ilíada y, sobre todo, en la Odisea, Heródoto de Halicarnaso otorga a las mujeres una presencia muy destacada en su única obra conocida, las Historias. Habitualmente, las mujeres que aparecen en esta obra están directamente emparentadas con personajes masculinos importantes. En este sentido, el de hija constituye uno de los papeles más representativos que desempeñan las mujeres en las Historias de Heródoto. Doce de las mujeres que intervienen activamente en la narración del autor de Halicarnaso son identificadas como hijas de reyes, tiranos u otros hombres nobles, tanto griegos como bárbaros. Entre los ejemplos disponibles, en este artículo nos centramos en tres princesas egipcias, hijas de los faraones Rampsinito, Kéops y Amasis —o, en realidad, Apríes-, porque constituyen casos particularmente interesantes para explorar las tensiones dentro de las relaciones paternofiliales en la obra herodotea. Nuestro objetivo es determinar si estas princesas se realizan individualmente como personajes, aun siendo hijas dominadas sexualmente por sus padres, biológicos o putativos. Para ello, realizamos un análisis en profundidad de los tres pasajes en que ellas aparecen (Hdt. 2.121e; 2.126; 3.1), teniendo en cuenta por qué y en qué circunstancias son controladas sexualmente, cómo interactúan con sus padres y con los demás personajes masculinos y qué consecuencias tiene sobre ellas el control sexual al que se ven sometidas. Los resultados muestran que las tres princesas de Egipto se realizan, respectivamente, como esposa, constructora y vengadora. Concluimos que Heródoto les confiere visibilidad, dignidad y un carácter propio e intransferible.

Palabras clave: concubinato; hijas; padres; visión de los griegos sobre el Antiguo Egipto; Historias de Heródoto; prostitución. 


\section{INTRODUCTION}

In the heat of second-wave feminism, Carolyn Dewald publishes an influential essay, "Women and Culture in Herodotus' Histories». She vindicates there the relevance of women in the work of the Halicarnassian author. In her study, the American classical scholar discusses daughters who «act as their fathers' agents in the public sphere and defend family interests when they are threatened» (Dewald, 1981, p. 105).

Among the twelve daughters that she lists (Dewald, 1981, p. 122), we focus on the progeny of the pharaohs Rhampsinitus, Cheops and Amasis or rather actually Apries- The three women act on behalf of their fathers in a context of sexual domination. This context fits the Greek stereotype that the Egyptians and their womenfolk are lewd (FGrHist. 688, F 13a; Irwin, 2017, p. 100; Sousa, 2020, pp. 208-209). Aside from the stereotype, given that the pharaohs exercise control over their daughters' sexual activity, their paternal filial relationships are fraught with a tension worth exploring. As for the children of Rhampsinitus and Cheops, domination takes the form of sexual exploitation, while for Apries' child, it manifests itself as concubinage.

This paper aims at ascertaining whether and to what extent these three female characters achieve individual fulfilment within the framework of their role as sexually dominated daughters. To this end, we draw up a characterisation of each woman on the grounds of an in-depth analysis of the passage where they feature. We conduct our research by considering the following aspects: why the sexual activity of each princess is subject to domination, what the circumstances of this domination are, how each princess interacts with male characters other than the pharaohs, and finally what consequences the controlled sexual activity has for each princess.

For the sake of coherence and completeness, we carry out the characterisation of the daughters of Rhampsinitus, Cheops and Apries in a single section, divided into three subsections, one for each princess. We also devote another whole, shorter, section to the conclusions.

\section{CHARACTERISATION}

Based on their most salient personality traits, we develop the ensuing characterisations of the three princesses in their capacity as daughters of pharaohs: 


\subsection{The submissive daughter}

The famous story of Rhampsinitus and the thief (Hdt. 2.121) is an old folktale, told with variations in different times and cultures (Munson, 1993, p. 38; Ruiz Sánchez, 2009, pp. 239-240).

Herodotus reports his account in indirect speech, relying on an implicit Egyptian source (Hdt. 2.121: غ̌ $\lambda \varepsilon \gamma o v$, «they said»). Rhampsinitus has a stone treasure chamber (oik $\uparrow \mu \alpha$ ) built to keep his immense riches. As intruders enter and leave the chamber unnoticed thanks to a movable stone (Hdt. 2.121 $\alpha$ ), he suffers three apparently impossible thefts. His three attempts to catch the thief evolve into a cunning competition between the pharaoh and his rival (Russo \& Simon, 2017, p. 135). As a result of the first one, the burglar decapitates his own brother and accomplice and escapes with his head, so that the body cannot be identified $(2.121 \alpha-\beta)$. When he returns home, his widowed mother insists that he rescue his brother's body even at the peril of his own life. Coerced by her, the thief participates in the second attempt. He evades surveillance and retrieves the corpse $(2.121 \gamma-\delta)$. Determined to apprehend the burglar at all costs, Rhampsinitus takes an extreme step on his third attempt:

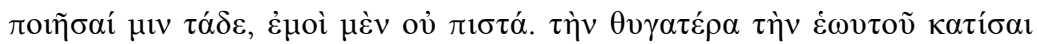

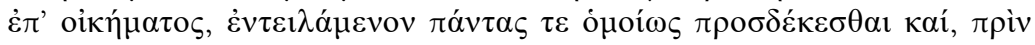

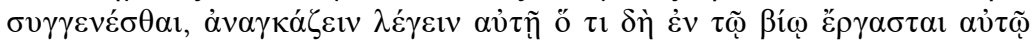

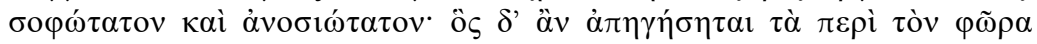

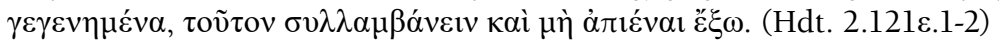

[They said that the king] did as follows, although I do not believe it. He put his own daughter in a brothel, ordering her to have relations with all alike and, before sleeping with them, force them to tell her the cleverest and most impious thing they had done in their life. Whoever told her the story of the thief, she was to grab and not let go ${ }^{2}$.

Herodotus is not judgmental about the burglary and its countermeasures, but interferes as a narrator to express scepticism (Pelling, 2019, p. 207; Boedeker, 2011 , p. 228, n. 67). Beneath this scepticism lies a scandalised attitude towards a monarch who prostitutes his anonymous daughter. Herodotus'

2. All translations are mine. Greek texts of Herodotus' Books II and III are taken from Lloyd \& Fraschetti (1996) and Asheri, Medaglia \& Fraschetti (1990), respectively.

Feminismo/s 39, January 2022, 267-285 
latent disgust is shared by modern readers and commentators, who take a dim view of Rhampsinitus for degrading his child (Ruiz Sánchez, 2009, p. 243; Bichler, 2018, p. 93). Neitzel (1993) is indeed so appalled that he denies that the princess engages in sexual intercourse. However, both a close reading of the text and the case of Cheops' daughter ${ }^{3}$ invite us to reject this puritanical interpretation (Wesselmann, 2011, p. 283, n. 776).

As we have seen, the thief's mother compels him to challenge the pharaoh for a second time. In contrast, Herodotus does not tackle the issue of the princess' consent or lack thereof. We do not know whether she does it voluntarily or not, but she complies with her father's instructions (Hdt. 2.121e.3) and acts as an erotic «bait» (Lateiner, 2015, p. 104; Bichler, 2018, p. 91). Since the Halicarnassian does not describe her physically either, her sex appeal resides exclusively in her lineage.

We should point out that Rhampsinitus does not transform his daughter into a courtesan for whose services only affluent clients can pay. As he ignores to which social class the thief belongs, he sets her up in a vulgar house of prostitution (oîk $\mu \alpha$ ). As a monarch's daughter, who is sexually accessible to anyone, the girl is supposed to attract as many men as possible. Herodotus omits meetings with other men in favour of her encounter with the burglar. He approaches the princess too, but not —or, at least, not only- for ghoulish fascination.

The thief knows the reasons behind Rhampsinitus' move (Hdt. 2.121ع.3:

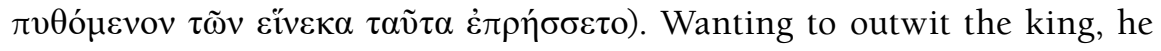
visits his daughter with a dead man's arm under his cloak. Both the whole episode's and the arm's infernal and folkloric resonances have been already analysed and are beyond the paper's scope (Aly, 1921, pp. 67-68; Wesselmann, 2011, pp. 285-287; Russo \& Simon, 2017, p. 138). From a logical point of view, Rhampsinitus' trap has a major flaw: his daughter faces the task of stopping the thief alone, without support, weapons or specific physical training (Neitzel, 1993, p. 234). Even without the dead man's arm, a young and healthy man like the burglar might easily get away from such an opponent. But precisely this logical flaw allows the princess to gain prominence,

3. See below subsection 2.2 .

Feminismo/s 39, January 2022, 267-285 
reducing the third capture attempt to a vis-à-vis interaction between her and the thief.

Like all other clients, he has to pay in advance for her sexual services. The price is not money, but information. As the socially superior, the princess ought to control the situation; she is to force her sexual partner to talk. The thief seems to yield, as he confesses that he impiously decapitated his brother and then cleverly stole his corpse from the guards (Hdt. 2.121ع.4). In reality, he is in charge. When she tries to seize him in the dark, the burglar holds out the dead man's arm to her and flees, leaving her clutching a mutilated limb (Hdt. 2.121e.5). Purves (2013, p. 39) rightly notes that fumbling in the dark replaces the sexual act. That is, while skipping the lascivious particulars, Herodotus dwells on a macabre and spicy humorous chase game that replicates the one between the pharaoh and the thief. He preserves a minimum of decorum and highlights the latter's astuteness.

Given that the fish does not take the bait, Rhampsinitus applies the maxim if you cannot beat them, join them. He sends messengers all over the country, promising immunity and a great reward to the burglar if he comes

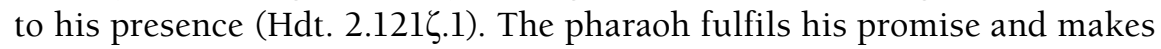
the thief his son-in-law.

Nothing in the text suggests that the thief must return what he took from the treasure chamber in exchange for this privilege. Thus, he joins the royal family and retains the stolen wealth, which will surely help him in his new life as a prince. This happy ending, characteristic of folktales and myths, deviates slightly from the typical one in that the burglar does not succeed Rhampsinitus (Wesselmann, 2011, p. 292; Luraghi, 2013, p. 104). Although a robber by the name of Amasis shall in time seat on the Egyptian throne (Hdt. 2.174; Griffiths, 2001, pp. 75-76) and worry about his daughter's sexual activity $^{4}$, he is not Rhampsinitus' immediate successor. This honour goes to Cheops (Hdt. 2.124.1), whose relationship with Rhampsinitus is not clear, but who treats his daughter very much like his predecessor treated his own, as we shall see straightaway.

For now, let us return to our thief's advantageous marriage. Rhampsinitus

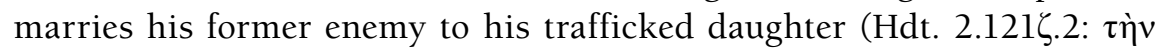

4. See below subsection 2.3.

Feminismo/s 39, January 2022, 267-285 
$\theta v \gamma \alpha \tau \varepsilon \dot{\varepsilon} \rho \tau \alpha v^{\tau} \eta \nu$, this daughter»). According to a widespread patriarchal prejudice, too much sexual experience undermines women's marriage prospects. Griffiths (2001, p. 75) falls into this bias when saying that the burglar weds the princess «in spite of her now far-from-virginal state». He seems to insinuate that Rhampsinitus should have betrothed an intact female relative of his to the thief. Instead, the pharaoh chooses the daughter with a past. To Griffiths' astonishment, the groom agrees.

Therefore, sex work does not render this daughter ineligible as a bride either in her father's or her spouse's eyes. Put it more bluntly, her experience in the brothel does not disgrace her, quite the opposite. She does and says only what her father instructs her to do, and receives a prize for her obedience: she stops practising prostitution and gets married. She does not take to husband just an average man. At the time of their marriage, the lowborn thief is already rich. In her father's authoritative opinion, he is also the shrewdest of all Egyptians. In line with the chauvinistic mindset that ranks the Egyptians as the brightest of all peoples (Lloyd \& Fraschetti, 1996, p.

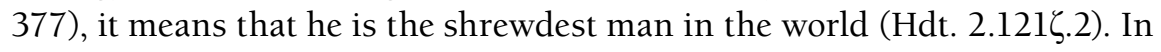
sum, Rhampsinitus' submissive daughter marries well.

\subsection{The proud daughter}

Cheops has his people labouring for decades on the Great Pyramid of Giza (Hdt. 2.124-126). This constructive feat occupies practically all the space Herodotus devotes to the reign of Rhampsinitus' immediate successor.

It is often taken for granted that the Halicarnassian diminishes the pyramid's splendour by presenting it as a token of despotic abuse of power (Steiner, 1994, p. 138; Kurke, 1999, p. 222; Lidov, 2002, p. 209; Bichler, 2018, p. 93). Not for nothing, his subjects strive to forget Cheops. They prefer not to name him and consequently attribute his pyramid to an obscure shepherd called Philitis (Hdt. 2.128). Even so, as Clarke (2015, pp. 44-45) demonstrates, Herodotus does not collaborate with this damnatio memoriae, since he names Cheops. Nor does he actively endorse Cheops' negative characterisation, for the episode is reported in indirect speech.

In other words, the condemnation of the Pharaoh's scandalous behaviour is explicit, but voiced by the Egyptians and not by the narrator (Hdt. 
2.124.1: "̌̀ $\overline{\varepsilon \gamma o v, ~ « t h e y ~ s a i d ») . ~ C h e o p s ~ i s ~ s a i d ~ t o ~ b e ~ s o ~ w i c k e d ~ t h a t ~ h e ~ p u t s ~ h i s ~}$

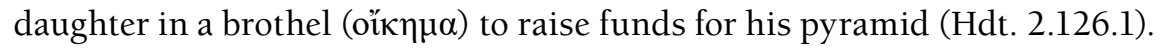
The narrative focus shifts quickly to the princess:

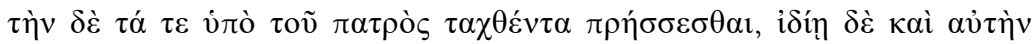

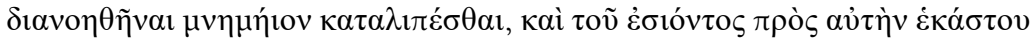

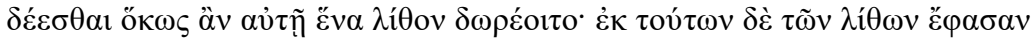

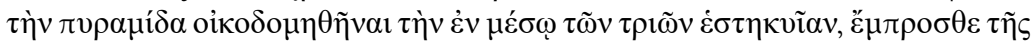

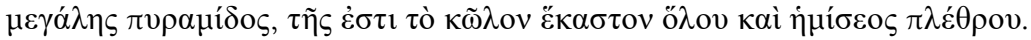
(Hdt. 2.126.1-2)

[They said that] she did what her father had ordered her to do, but on her own initiative she had the idea of leaving a monument to herself. So she asked each one who came in to see her to give her a stone. And of these stones, they claim, the pyramid was built that stands between the three, in front of the Great Pyramid. Each of its sides measures one and a half plethra .

This passage shares obvious commonalities with the one examined in the previous subsection. Nonetheless, each tale has an entity of its own. Like Rhampsinitus' one, Cheops' daughter is anonymous, and it is not known whether she consents or is forced into prostitution. At any rate, she is used as an erotic bait too. Her sex appeal lies equally in her bloodline, for she is not described. Like his predecessor, Cheops could have made a courtesan of his daughter or, at least, placed her in an establishment for an upper-class clientele, but he opts for a vulgar house of ill repute. There, he can count on many ordinary men willing to have sex with her for ghoulish fascination. There is no evidence that these men attain anything other than satisfying their desire, curiosity or both.

Notwithstanding, lurid details are left to the readers' imagination. The Halicarnassian is more delicate with Cheops' daughter than with that of Rhampsinitus. He does not mention intercourse at all. He does not even hint at any physical contact between the princess and her sexual partners. Their recorded interaction is purely dialogical.

There are still more substantial differences. If Rhampsinitus is looking for information, Cheops wants money. He sets an economic objective. His

5. That is, each side measures approximately 44.5 metres.

Feminismo/s 39, January 2022, 267-285 
daughter must earn a specific sum of money, but Herodotus admits to a shortage in his source: he has not been told how much (Hdt. 2.126.1: ov̉ yò $\rho$

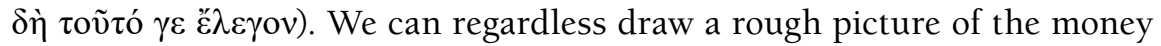
that she gathers in the light of another story, where a prostitute is also said to have built a pyramid. Herodotus refutes the claim that Rhodopis, a very successful Thracian courtesan, earns enough money in Egypt to bear the expense of such a structure (Hdt. 2.135.2). If the Egyptian princess allegedly accomplishes what the Thracian girl cannot, it follows that the former receives more paying visitors, and hence produces even more benefit than the latter.

This parallel makes it clear that his daughter's sex work provides Cheops with a tremendously high income. The fact that the exact amount required by the sovereign remains unrevealed has also a narrative purpose. It suggests that, despite appearances, neither Cheops nor his child cherish money per se. This pharaoh does not covet money to store it like Rhampsinitus, but to pay for a monument that perpetuates his memory beyond his lifetime. His daughter hands over her earnings to him and adopts his aspirations (Vasunia, 2001, p. 84). Contrary to the Great Pyramid, hers does not seem to result from an organised endeavour orchestrated by an omnipotent leader, but from a myriad of small favours. Besides, Herodotus is not as interested in the object itself or its construction as its symbolic value for the princess.

A stele confirms that a pyramid in Giza was named after a daughter of Cheops (Konstantakos, 2018, p. 95). In the Histories, the princess' pyramid corresponds to the middle one in a group of three small pyramids lined up from north to south, on the south-eastern side of the Great Pyramid (Lloyd \& Fraschetti, 1996, p. 346).

As the socially superior person in her encounters with men, Cheops' daughter is in control and assumes an absolute protagonism, whereas her clients do not stand out; they are indistinguishable from each other. She spontaneously charges each of them an additional fee, a stone. We are not told from where these come, but each one evokes the extraction, transportation, polishing and placement of stones in the Great Pyramid (Hdt. 2.124-125). At the same time, every stone is crucial to the princess, just as the movable stone in Rhampsinitus' treasure chamber is to the thief. 
More broadly, the fee has masculine, warlike connotations. Homeric warriors sometimes wound their enemies by throwing stones at them (e.g. Hom. Il. 5.308; 8.327). During the Scythian campaign, king Darius of Persia orders each of his soldiers to leave a stone by a river to mark their passing with great piles (Hdt. 4.92). Similarly, Cheops' daughter has her pyramid erected with the stones supplied by her clients.

As Hollmann (2011, p. 202) remarks, each stone represents not a fighter under her command, but a bedfellow who has paid twice for the princess' services. In this respect, the construction challenges the patriarchal thinking that equates women's good reputation with chastity or, failing that, pretence of chastity (Bourdieu, 2000, p. 63). Far from feeling ashamed, Cheops' daughter asserts herself in a very public and durable way.

We should not make the mistake of seeing the Herodotean account or the oral tradition that serves as its basis as being feminist avant la lettre. While keeping as much decorum as possible, Herodotus is cognisant of the shocking nature and spicy humour inherent in this anecdote (Lateiner, 2015, p. 103). Otherwise stated, he expects his target audience to abhor and simultaneously laugh at the behaviours of both the pimp pharaoh and his trafficked daughter. The Halicarnassian exploits narratively prejudices that are not exclusive to ancient societies, but persist in modern ones (del Barrio Álvarez, 2018, pp. 45-46). Nevertheless, he also reflects the princess' outlook.

Von Reden (1997, p. 173) maintains that how the collected stones are used restores her honour. However, the text does not indicate that the princess perceives her experience in the brothel as a disgrace. She does not celebrate promiscuity itself either, but her performance. After all, she has been instrumental in financing her father's grand project. This sense of accomplishment drives her to immortalise her contribution in the Pharaonic fashion, with a pyramid (Vasunia, 2001, p. 83).

The pyramid bears witness to her self-reliance too. As opposed to Rhampsinitus' daughter, she does not rely on her father to reap the fruits of her obedience and work. Nor does she need a sagacious and rich husband to find her happy ending in the story. Cheops' proud daughter grants herself the right to be remembered by future generations and seeks the means to that end. Simply by requesting it from her customers, she obtains the necessary material to raise her memorial. 


\subsection{The resentful daughter}

Herodotus announces Egypt's invasion by king Cambyses of Persia at the beginning of Book 2 (Hdt. 2.1.2), but he does not pick it up until Book 3. He creates a complex web of alternatives to explain why Cambyses launches his victorious campaign (Hdt. 3.1-3). All three explanations, scrutinised by Irwin (2017), stem from a different source -Persian, Egyptian and unidentified - and revolve around the personal relationship between the Persian king and an Egyptian princess. The Halicarnassian thus lends a touch of spicy humour to a momentous military decision. Bedroom affairs and harem feuds trigger Egypt's annexation to the Persian Empire (Pelling, 2016, p. 69).

Due to its concomitances with the previously discussed passages, we concentrate on the first and most extended explanation, ascribed to the

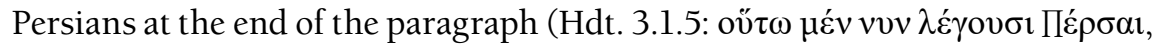
«So the Persians say»). After his transfer to Persia at Amasis' behest, the best Egyptian eye-doctor is angry about being separated from his family. He then persuades Cambyses to ask Amasis for a daughter, and the pharaoh sends someone else's daughter. Cambyses and this woman have a conversation, whose most important part is conveyed in direct speech:

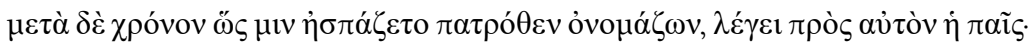

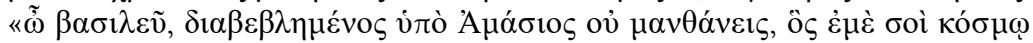

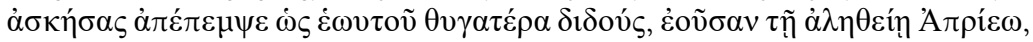

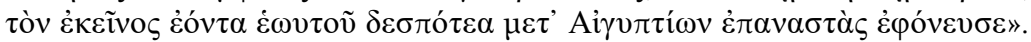
(Hdt. 3.1.4)

After some time, Cambyses greeted her by her father's name and then the girl said to him: "Your Majesty, you don't realise that you have been duped by Amasis, who adorned me and sent me to you as if he gave away his own daughter, although I am actually that of Apries, the sovereign against whom he rebelled together with the Egyptians and whom he murdered».

Amasis' concern for his anonymous child is at variance with Rhampsinitus' and Cheops' exploitation of their daughters. But it is also at odds with his psychological abuse against his wife just two chapters above (Hdt. 2.181; Suárez de la Torre, 2020, p. 214). Although it may be motivated by affection (Baragwanath, 2015, p. 25), Amasis' anxiety mainly mirrors the ophthalmologist's longing for his beloved ones. On the principle of an eye for an eye, the pharaoh should miss his daughter were he to part with her. If he kept her 
by his side, he would risk a diplomatic rift. Moreover, Amasis knows that Cambyses does not intend to marry the girl, but to impose cohabitation on

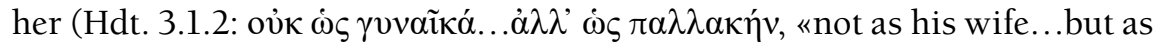
his concubine»). Caught in the dilemma of letting her go or offending a formidable neighbour, Amasis devises a scheme worthy of Rhampsinitus' thief.

Fraudulent wife switch is a recurrent theme in Mediterranean and Near Eastern folklore (Gen. 29.21-27; Asheri, Medaglia \& Fraschetti, 1990, p. 214). The pharaoh swaps his daughter for Nitetis, a girl probably of her age (contra Irwin, 2017, p. 104), whom he holds captive.

As with Rhampsinitus and Cheops' daughters, Herodotus does not deal with Nitetis' consent or lack thereof. Be that as it may, she serves as an erotic bait too. Herodotus insists that Amasis clothes Nitetis in gold and fine attire, first in his own narratorial voice and again in the character's. She is hence dressed princely and seductively. Cambyses is a reigning king that assumes her to be the daughter of a counterpart, so her sex appeal does not depend on his (ghoulish) fascination with her status. It rests instead on her appearance. Described as very tall and beautiful, Nitetis qualifies for sexual gratification.

Nevertheless, her interaction with Cambyses is, as Pelling (2019, p. 131) defines it, «hardly lubricious». He speaks to her respectfully, using her patronymic. It is not stated, but we can infer that he calls her «daughter of Amasis». This inaccuracy implies that Cambyses, albeit the socially superior and the dialogue initiator, does not fully control the situation. By addressing him with the style of majesty, the concubine formally recognises his pre-eminence.

Even so, she corrects him, proving to be in charge. Years earlier, the Egyptians had revolted against her father, pharaoh Apries, and Amasis betrayed his lord. He joined the insurrection, appropriated the crown and surrendered Apries to the mob, who strangled him (Hdt. 2.161-169). Nitetis exposes Amasis and the Egyptians as cheaters, rebels and murderers succinctly and dispassionately (Bowie, 2018, p. 35). Upon hearing her, the Persian king realises that Amasis has deceived him. Outraged, he attacks Egypt (Hdt. 3.1.5). Insofar as she lights the fuse of war without lying, evincing feelings or telling Cambyses what to do, Apries' daughter exhibits her sharp intelligence, which stands comparison with that of Amasis. 
Herodotean Amasis observes concubinage through Greek lenses, believing that it subjects women to men's whims without the legal security of marriage (e.g. Hdt. 6.138; Antipho 1.14; Ar. V. 1350-1353). A Persian custom known to the Egyptians grounds this belief: bastards begotten by concubines do not inherit the Persian throne if there are royal offspring born in wedlock (Hdt. 3.2.2). With no chance of succession for his grandchildren, Amasis would consider Cambyses' demand scandalous and be reluctant to sacrifice his daughter's honour and his own. However, as far as we know, these prejudiced images do not conform to the reality of the Persian king's concubines and their children (Brosius, 1996, p. 47; Llewellyn-Jones, 2013, pp. 117-118).

Therefore, concubinage does not disgrace Nitetis. Like Rhampsinitus' and Cheops' daughters, she benefits from her experience in the harem, although her advantage is less tangible than a husband or a pyramid. She gets her particular happy ending: revenge, which incidentally also accommodates the ophthalmologist's interest (Boedeker, 2011, p. 217). Like the burglar, Cambyses wins too.

Herodotus engages both his readers and Cambyses in a game of true and false genealogies that prefigures «the doubtful accounting of Darius' own ascension later in Book 3» (McKeon, 2020, p. 375). At first glance, being the daughter of an ex-king disguised as a princess, Nitetis has dubious and obsolete royal credentials. In fact, Amasis' daughter, as the child of an illegal king, is a fraud. In her capacity as the only surviving member of Egypt's last rightful dynasty (Hdt. 3.1.3), Nitetis is the genuine princess, and the only female character with a proper name in the three stories surveyed.

By blaming Amasis and the entire Egyptian people for overthrowing and killing Apries, she furnishes the Persians with a casus belli. Further, his relationship with Nitetis adds legitimacy to Cambyses' conquest, helping him transcend the category of mere occupier to a lasting ruler (Tourraix, 1976, p. 377; Blok, 2002, p. 232; Aissaoui, 2020, p. 20). As anticipated, Nitetis retaliates. She manages to deprive the Egyptians of their independence. Given that she accuses Amasis of assassination and vengeance for a slain person must always be aimed at the perpetrator (Varias, 1998, p. 29), Nitetis ought to inflict harm on him too. Nonetheless, Amasis is already dead. Irwin (2017, p. 102) argues that women swapping only buys time for the tricky pharaoh. 
It buys just enough time, though, because Amasis does not live to see his country in foreign hands.

On his demise, he is embalmed in a splendid tomb. The Halicarnassian interprets Cambyses' desecration of the corpse as a sacrilege against Persian and Egyptian morals (Hdt. 3.16). It is a symptom of his deteriorating mental state (Rood, 2006, p. 299), which later degenerates into madness (Hdt. 3.2737). From Nitetis' perspective, this irrational violence takes on the tinge of retaliation against a criminal usurper, undeserving of a royal burial place (Bowie, 2018, pp. 35-36).

Nitetis' vengeance has feminine connotations. It is subtle, since Herodotus does not name her when depicting the Egyptians' subjugation to Persia or the mistreatment of Amasis' mummy. As one would expect from a defenceless person, she does not exact her revenge herself, but by proxy. Apries' resentful daughter avails herself of her proximity to Cambyses to enlist him as her agent. He is ideally suited to the task, being powerful enough to punish all those responsible for her father's deposition and her family's destruction.

\section{CONCLUSION}

The studied episodes pivot on the sexual commodification of three women by pharaohs who either are or pretend to be their fathers. Rhampsinitus, Cheops and Amasis use their real or presumed daughters as an erotic bait for acquisitive purposes, to procure information, money for an eternal monument and time. For men as mighty and wealthy as reigning kings to commodify their daughters is scandalous. Herodotus is mindful of this, regardless of whether he incorporates it explicitly in his text as his sources' opinion or whether he keeps it implicit. Notwithstanding, he does not handle these scandals seriously, but comically. He displays a spicy, albeit not obscene, humour, capitalising on the stereotype of lecherous Egyptians.

This approach clashes with current sensibilities. In like fashion, Herodotus' silence on these women's sexual consent can be bewildering today, when it is such a burning issue (Mañas Viejo \& Martínez Sanz, 2020, p. 239). Whether or not the princesses agree to prostitution or concubinage has no place in his account. On the one hand, his silence attests to the cultural and value gap between the Halicarnassian and us. On the other, it also 
underlines the objectification of the three women. It is not just that they have not a say in their sexual activity. Neither the narrator nor his sources nor any of the characters even contemplate that they might have it.

Therein runs the paradox common to all three passages. Sexual commodification and objectification result in these women realising themselves as individuals in the narrative. They achieve individual fulfilment through two strategies: emulation and revelation of the truth.

The daughters of Rhampsinitus and Cheops emulate their fathers. Anonymity underpins emulation. It is not surprising for princesses identified only by their fathers' names to behave like them. Tantamount to her father, Rhampsinitus' daughter plays chase with the thief. She should be in charge of their interaction, but the game dynamics are the same as between the pharaoh and the burglar: the latter is in control. Cheops' daughter shares her father's ambition to live forever in the memory of generations to come. Accordingly, she has a pyramid built too. Just as Cheops has mastery over the Egyptian people, his daughter controls her interactions with the male suppliers of stones for her memorial. Nevertheless, since it is rooted in request, her control is lighter than Cheops' despotism.

Being dethroned and dying a violent death, Apries is not a role model for his daughter. Without a father to imitate, she has a more defined personality than the other princesses, thanks to which she sparks a military operation that changes her country's history. Perhaps, for these reasons, her name is recorded. Nitetis opts for a simple, effective strategy of individual fulfilment. She becomes her family's avenger by disclosing who her true father was and what fate befell him. Against the odds, she controls her interaction with Cambyses, because she points the course for him to follow despite her helplessness.

Indeed, Amasis safeguards his own daughter's honour by turning Nitetis into a concubine. Sexual degradation is more blatant in the cases of the prostituted daughters of Rhampsinitus and Cheops. At any rate, the hegemonic patriarchal power embodied by the three Egyptian monarchs attacks all these women's dignity. Exceptionally, they do not emerge disgraced from the aggression, with which they cope in different ways. Rhampsinitus' daughter bows to her father's designs, practising sex work until she enters into a marriage arranged by the pharaoh. Thereby, her submission to the representative 
of hegemonic patriarchal power that exploits her enables her to escape sexual degradation, preserve her dignity as a princess and, perhaps, recover her place at court.

In contrast, the other two females put up a surreptitious resistance. Cheops' daughter takes pride in her fundraising effort and commemorates it in an open, masculine manner. It clearly shows that she never forgets her place at the pinnacle of Egyptian society. Though she is not stated as quitting prostitution, she remains fully self-aware of her dignity as a princess. For her part, Nitetis passes on her resentment against Amasis to Cambyses in an ingenious and feminine style. She counters the hegemonic patriarchal power wielded by her oppressor with a foreign counter-power of the same kind, personified by the Persian king. She thus requites the downfall of her dynasty. In the process, even if there is no indication of her leaving concubinage behind, she also reaffirms her dignity as the last legitimate princess of Egypt.

Rhampsinitus', Cheops' and Apries' daughters pale in the shadow of the male rulers with whom they are related in the narrative; they are undoubtedly secondary figures. Nonetheless, Herodotus affords them a glimmer of visibility, endowing them with their own non-transferable characterisation and with dignity in debasing circumstances. In short, he gives them a voice. In doing so, the Halicarnassian offers readers a deep, yet humorous, insight into how the three princesses confront the family, gender, political and sexual constraints that Egyptian and Greek ancient societies foist even on most privileged women.

\section{REFERENCES}

Aissaoui, A. I. (2020). Diplomacy in Ancient Times: The Figure of Udjahorresnet: An International Relations Perspective. Journal of Ancient Egyptian Interconnections, 26, 12-34.

Aly, W. (1921). Volksmärchen, Sage und Novelle bei Herodot und seinen Zeitgenossen. Eine Untersuchung über die Volkstümlichen Elemente der Altgriechischen Prosaerzählung. Vanderhoeck \& Ruprecht.

Asheri, D., Medaglia, S. \& Fraschetti, A. (1990). Erodoto. Le Storie. Libro III. La Persia. Mondadori. 
Baragwanath, E. (2015). Characterization in Herodotus. In R. Ash, J. Mossman \& F. B. Titchener (Eds.), Fame and Infamy: Essays on Characterization in Greek and Roman Biography and Historiography (pp. 17-35). Oxford University Press. https://doi.org/10.1093/acprof:oso/9780199662326.003.0002

del Barrio Álvarez, E. (2018). Satisfacción revolucionaria. Un modelo de intervención psicológica para supervivientes de trata que hacen trabajo sexual después de los 40. Feminismo/s, 31, 39-63. https://doi.org/10.14198/ fem.2018.31.02

Bichler, R. (2018). Herodotus' Book 2 and the Unity of the Work. In T. Harrison \& E. Irwin (Eds.), Interpreting Herodotus (pp. 75-98). Oxford University Press. https://doi.org/10.1093/oso/9780198803614.003.0004

Blok, J. (2002). Women in Herodotus. In E. J. Bakker, I. J. F. de Jong \& H. van Wees (Eds.), Brill's Companion to Herodotus (pp. 225-242). Brill. https://doi. org/10.1163/9789004217584_011

Boedeker, D. (2011). Persian Gender Relations as Historical Motives in Herodotus. In R. Rollinger, B. Truschnegg \& R. Bichler (Eds.), Herodot und das Persische Weltreich (pp. 211-235). Harrassowitz Verlag.

Bourdieu, P. (2000). La dominación masculina (J. Jordá, Trad.). Anagrama.

Bowie, A. (2018). Herodotus the Story-teller. In E. Bowie (ed.), Herodotus. Narrator, Scientist, Historian (pp. 25-36). De Gruyter. https://doi. org/10.1515/9783110583557-002

Brosius, M. (1996). Women in Ancient Persia (559-531 BC). Clarendon Press.

Clarke, K. (2015). Putting up Pyramids, Characterizing Kings. In R. Ash, J. Mossman \& F. B. Titchener (Eds.), Fame and Infamy: Essays on Characterization in Greek and Roman Biography and Historiography (pp. 37-51). Oxford University Press. https://doi.org/10.1093/acprof: oso/9780199662326.003.0003

Dewald, C. (1981). Women and Culture in Herodotus' Histories, in H. Foley (Ed.), Reflections of Women in Antiquity (pp. 91-125). Routledge.

Griffiths, A. (2001). Behind the Lines: the Genesis of Stories in Herodotus. In F. Budelmann \& P. Michelakis (Eds.), Homer, Tragedy and Beyond: Essays in Honour of P. E. Easterling (pp. 75-89). Society for the Promotion of Hellenic Studies.

Hollmann, A. (2011). The Master of Signs. Signs and the Interpretation of Signs in Herodotus' Histories. Harvard University Press. 
Irwin, E. (2017). Just Why Did Cambyses Conquer Egypt? Herodotus' Logos of Cambyses' Egyptian Campaign: His Story as History. In R. Rollinger (Ed.), Die Sicht auf die Welt zwischen Ost und West (750 v. Chr. 550 n. Chr.) (pp. 95-141). Harrassowitz Verlag. https://doi.org/10.2307/j.ctvc2rmq3.7

Konstantakos, I. (2018). Time, Thy Pyramids: The Novella of Mycerinus (Herodotus 2.129-134). In E. Bowie (Ed.), Herodotus. Narrator, Scientist, Historian (pp. 77-107). De Gruyter. https://doi.org/10.1515/9783110583557-005

Kurke, L (1999). Coins, Bodies, Games, and Gold: The Politics of Meaning in Archaic Greece. Princeton University Press.

Lateiner, D. (2015). Ou kata nomon: Obscene Acts and Objects in Herodotus' Histories. In D. Dutsch \& A. Suter (Eds.), Ancient Obscenities. Their Nature and Use in the Ancient Greek and Roman Worlds (pp. 91-124). The University of Michigan Press.

Lidov, J. B. (2002). Sappho, Herodotus and the Hetaira. Classical Philology, 97(3), 203-237. https://doi.org/10.1086/449585

Llewellyn-Jones, L. (2013). King and Court in Ancient Persia 559 to 331 BC. Edinburgh University Press.

Lloyd, A. \& Fraschetti, A. (1996). Erodoto. Le Storie. Libro II. L'Egitto. Mondadori. Luraghi, N. (2013). The Stories before the Histories: Folktale and Traditional Narrative in Herodotus. In R. V. Munson (Ed.), Oxford Readings in Classical Studies. Herodotus. Volume 1 (pp. 87-112). Oxford University Press.

Mañas Viejo, C. \& Martínez Sanz, A. (2020). Between Coercion and Consent: A Study on Male Sexual Violence in Heterosexual Partner Relationships. Masculinities \& Social Changes, 6(3), 235-260. https://doi.org/10.17583/ mcs.2020.5663

McKeon, K. P. J. (2020). Barbarians at the Gate: Herodotus, Bisotun, and a Persian Punishment in Egypt. The American Journal of Philology, 141(3), 349-380. https://doi.org/10.1353/ajp.2020.0020

Munson, R. V. (1993). Herodotus' Use of Prospective Sentences and the Story of Rhampsinitus and the Thief in the Histories. The American Journal of Philology, 114(1), 27-44. https://doi.org/10.2307/295380

Neitzel, H. (1993). Prinzessin und Meisterdieb bei Herodot (2, 121 ع). Würzburger Jahrbücher für die Altertumswissenschaft, 19, 215-238.

Pelling, C. (2016). Herodotus' Persian Stories: Narrative Shape and Historical Interpretation. Syllecta Classica, 27, 65-92. https://doi.org/10.1353/ syl.2017.0002 
Pelling, C. (2019). Herodotus and the Question Why. University of Texas Press.

Purves, A. (2013). Haptic Herodotus. In S. Butler \& A. Purves (Eds.), Synaesthesia and the Ancient Senses (pp. 27-41). Acumen.

von Reden, S. (1997). Money, Law and Exchange: Coinage in the Greek Polis. The Journal of Hellenic Studies, 117, 154-176. https://doi.org/10.2307/632554

Rood, T. (2006). Herodotus and Foreign Lands. In C. Dewald \& J. Marincola (Eds.), Cambridge Companion to Herodotus (pp. 290-305). Cambridge University Press. https://doi.org/10.1017/CCOL052183001X.020

Ruiz Sánchez, M. (2009). La mano cortada. Cuentos de ladrones de Heródoto a nuestros días (I). Myrtia, 24, 239-272.

Russo, J. \& Simon, B. (2017). Gambling with Demeter: Winning, Losing, and Successful Outcome in Herodotus' Histories. Arion 25(1), 131-160. https:// doi.org/10.2307/arion.25.1.0131

Sousa, R. (2020). Herodotus' Memphite Sources. In T. Figueira \& C. Soares (Eds.), Ethnicity and Identity in Herodotus (pp. 201-219). London. https://doi. org/10.4324/9781315209081-13

Suárez de la Torre, E. (2020). Women as Users of Erotic Spells: Evidence Provided by Papyri and Defixiones. In A. Mastrocinque, J. E. Sanzo \& M. Scapini (Eds.), Ancient Magic. Then and Now (pp. 211-232). Franz Steiner Verlag.

Steiner, D. (1994). The Tyrant's Writ. Myths and Images of Writing in Ancient Greece. Princeton University Press.

Tourraix, A. (1976). La femme et le pouvoir chez Hérodote. Essai d'histoire des mentalités antiques. Dialogues d'histoire ancienne, 2, 369-386. https://doi. org/10.3406/dha.1976.2920

Varias, C. (1998). La venjança del pare davant els tribunals en el Contra la madrastra d'Antifont. Faventia, 20(2), 27-31.

Vasunia, P. (2001). The Gift of the Nile: Hellenizing Egypt from Aeschylus to Alexander. University of California Press.

Wesselmann, K. (2011). Mythische Erzählstrukturen in Herodots Historien. De Gruyter. https://doi.org/10.1515/9783110239669 